\title{
Transkalliapseudes spinulata, new genus, new species (Crustacea: Tanaidacea: Kalliapseudidae) from the northwest Australian shelf
}

\author{
DAVID T. DRUMM \& RICHARD W. HEARD \\ Department of Coastal Sciences, University of Southern Mississippi, Gulf Coast Research Laboratory Cam-
} pus, Ocean Springs, MS 39566-7000.E-mail: David.Drumm@usm.edu

\begin{abstract}
A new kalliapseudid genus, Transkalliapseudes is erected to receive T. spinulata, n. sp. The description of the new genus and species are based on two males collected at depths of 44-82 m from the Northwest Continental Shelf of Australia. Transkalliapseudes $\mathrm{n}$. gen. shares most features (setation of uniarticulate mandibular palp, cheliped, and dactylus of pereopod I) with those of the subfamily Kalliapseudinae; however, the dactylus on pereopods IV-VI are similar to those found in the subfamily Hemikalliapseudinae, as well as, some species of Kalliapseudes. The presence of numerous granular-like spinules on appendages of T. spinulata appears to be a unique character. A key and table for the separation of the genera within the subfamily Kalliapseudinae is presented.
\end{abstract}

Key words: Crustacea, Tanaidacea, new genus, Transkalliapseudes spinulata, Australia

\section{Introduction}

While studying tanaidacean material collected during baseline studies on the Northwest Australian Continental Shelf, we came across two adult males belonging to the family Kalliapseudidae Lang, 1956. Upon further examination we determined that these specimens apparently represented a new genus with a unique mixture of characters that indicated a possible transition between the subfamilies Kalliapseudinae Lang, 1956 and Hemikalliapseudinae Guțu, 1972. The description of this new genus and species is presented in this report.

The terminology used follows Larsen (2003). Descriptions were generated from a DE LTA (Dallwitz et al. 1993) database. The material is deposited in the Australian Museum, Sydney (AM). Measurements were made with a stage micrometer and drawings were made with the aid of a drawing tube mounted on a Leitz microscope. 


\section{Suborder Apseudomorpha Sieg, 1980}

\section{Family Kalliapseudidae Lang, 1956}

\section{Subfamily Kalliapseudinae Lang, 1956}

Emended diagnosis (modified after Guțu 2006). Last pereonite short, about as long as first pleonite. Antennal peduncle with four or five articles. Large uniarticulate mandibular palp having numerous long plumose setae. Maxilliped palp having long plumose setae on last three articles. Cheliped having inner margins of carpus and propodus fringed with numerous long plumose setae; with or without exopodite. First pereopod with long merus and short carpus and propodus; dactylus short and thick, with a tuft of numerous aesthetascs; unguis absent; with or without exopodite. Dactylus of second and third pereopods slender, with or without a small digitiform prolongation ending in a few setae. Dactylus of fourth and fifth pereopods with a tuft of aesthetascs or with few distal setae; unguis absent. Dactylus of sixth pereopod with tuft of aesthetascs or claw-shaped. Males with or without sexually dimorphic chelipeds.

Remarks. The family Kalliapseudidae Lang, 1956 is currently divided into three subfamilies: Hemikalliapseudinae Guțu, 1972; Kalliapseudinae Lang, 1956; and Tanapseudinae Băcescu, 1978 (Guțu 2006). The subfamily Hemikalliapseudinae was erected to receive the genus Hemikalliapseudes Lang, 1956, characterized by having a 3articulate mandibular palp (Guțu 1972). The subfamily Tanapseudinae was originally described as a family and was reduced in rank and included in the family Sphyrapidae (Bamber 2000). Guțu (2001) and Hansknecht et al. (2002) transferred the Tanapseudinae to the family Kalliapseudidae. The members of the Tanapseudinae are characterized by having a small uniarticulated mandibular palp ending in a seta and the dactylus of pereopods I-V with a claw and at least a terminal seta (Guțu 2001). Based on the diagnostic characters as mentioned above, we assign our material from the shelf waters off northwestern Australia to the Kalliapseudinae.

The Kalliapseudinae has also been defined as having the dactylus of pereopods IV and V with a tuft of aesthetascs (Guțu 2001, 2006). There are, however, some species (i.e. Kalliapseudes langi Guțu, 2006; K. senegalensis Guțu, 2006; K. struthi Bamber, 2005; and the new genus described herein) that have only a few distal setae on the dactylus and we have amended the subfamily diagnosis to accommodate this fact.

\section{Genus Transkalliapseudes, new genus}

Diagnosis. Labial palp with a very elongate, acuminate inner tip. Inner lobe of moveable 
endite of maxilla with spiniform setae terminating in 3 cusps. Cheliped and pereopod I lacking exopodite. Pereopod I dactylus represented by a sensory organ terminating in a tuft of setae. Pereopod II and III dactylus with setose digitiform lobe. Pereopod IV and V dactylus with 2 distal sensory setae. Pereopod VI with dactylus bearing a single distal seta.

Type Species. Transkalliapseudes spinulata, new species, here designated.

Etymology. Formed from the Latin, Trans, meaning over, across, on or to the other side of, in combination with the generic name Kalliapseudes, alluding to having features in common with the subfamily Hemikalliapseudinae Guțu, 1972.

Remarks. As mentioned earlier the presence of a large uniarticulate mandibular palp and the distinctive setation of the mandibular palp, the carpus and propodus of the cheliped, and the dactylus of the first pereopod, place Transkalliapseudes, n. gen. within the subfamily Kalliapseudinae. The Kalliapseudinae currently contains five genera, Cristapseudes Bacescu, 1980; Kalliapseudes Stebbing, 1910 sensu Guțu, 2006; Mesokalliapseudes Lang, 1956; Monokalliapseudes Lang, 1956; and Alokalliapseudes Guțu, 2006.

Transkalliapseudes, n. g., can be differentiated from these five other genera by a combination of characters, most notably the lack of exopodites on the cheliped and pereopod I, the presence of setose sensory lobes on the dactylus of pereopods II and III, and the armature of the dactylus of pereopods IV-VI. It is distinguished from the genus Cristapseudes by possessing setose sensory lobes on the dactylus of pereopods II and III and by lacking an exopodite on the cheliped and pereopod I (Băcescu 1980; Guțu 1996, 2006; Bamber et al. 2003). The absence of an exopod on both the cheliped and pereopod I separates it from Kalliapseudes (Guțu 1996, 2006). The presence of a double row of plumose setae on the last article of the antennal peduncle distinguishes it from the genera Mesokalliapseudes and Alokalliapseudes. It differs from the genus Monokalliapseudes by the absence of an exopodite on pereopod I and the lack of a tuft of sensory setae on the dactylus of pereopod VI. Also, the armature of the dactylus on peropods IV--VI of the new genus strongly resembles some species in the Hemikalliapseudinae (e.g. Bacescapseudes patagoniensis Sieg, 1986).

We believe that this unique combination of characters discussed above justifies the erection of this new genus. Transkalliapseudes n.g., and the other five genera now assigned to the subfamily Kalliapseudinae can be distinguished by the following key and diagnostic table (Table 1).

Key for the separation of the six genera currently assigned to the subfamily Kalliapseudinae Lang, 1956 (modified in part from Guţu, 1996)

1. Cheliped without and pereopod I with exopodite; pereopod VI dactylus short, with tuft of sensory setae Monokalliapseudes Lang, 1956

Cheliped and pereopod I both lacking or both having exopodites; pereopod VI dacty- 
2. Cheliped and pereopod I with exopodite. Kalliapseudes Stebbing, 1910

Cheliped and pereopod I without exopodite

3. Pereopod II and III without digitiform lobe on dactylus.. Cristapseudes Băcescu, 1980

Pereopod II and III with digitiform lobe on dactylus.

4. Last peduncular article of antenna with plumose setae Transkalliapseudes n.g.

Last peduncular article of antenna with simple setae

5. Cheliped not distinctly sexually dimorphic Mesokalliapseudes Lang, 1956 Cheliped sexually dimorphic (male propodus much more robust than in female)

Alokalliapseudes Guțu, 2006

\section{Transkalliapseudes spinulata, new species}

Figs. 1-4

Material examined. Holotype: adult male, AM P56734, Northwest Shelf, Western Australia, 82 m depth, 195.2'S, 118 $57.6^{\circ} \mathrm{E}, \mathrm{CSIRO}$ on RV "Soela", 14 February 1983. Paratype: 1 adult male, AM P52195, Northwest Shelf, Western Australia, $44 \mathrm{~m}$ depth, 1956.4'S, 117'53.9'E, CSIRO on RV “Soela”, 25 June 1983.

Description. Holotype male. Body (Fig 1A): length $3.7 \mathrm{~mm}$, 4.8 times longer than broad.

Carapace (Fig. 1A). Broader than long, 1 pair mid-lateral setae; rostrum round.

Pereonites (Fig. 1A). 4 and 5 longer than 1-3, 6, rounded laterally; with 2 pairs of setae on dorsal surface; hyposphaenia (fig. 1B) present, shaped as a small round protuberance with a short distal spine on pereonite I and as a long spine on pereonites II-V. Pereonite VI with a genital cone (fig. 4C).

Pleon (Fig. 1A). Pleonites subequal; rounded epimera, with several plumose setae and 2 pairs of simple setae on dorsal surface; hyposphaenia (fig. 1C) present, shaped as a long spine on pleonite I and as a round protuberance with a short distal spine on pleonites II-V. Pleotelson about $1 / 2$ length of combined length of pleonites $1-5$, rounded, narrowing posteriorly to a bifurcated tip; with several lateral simple setae, several simple setae on dorsal surface, and 2 long plumose setae on either side of tip.

Antennule (Fig. 1D). First article about 2.5 times as long as second and third articles combined and about 3.5 times longer than maximum width; inner flagellum with 3 articles and outer flagellum with 8 articles, with numerous aesthetascs; 3 terminal simple setae.

Antennae (Fig. 1E). Article 1 with medial extension, bearing 4 plumose setae. Squama with 4 long simple setae. Last peduncle article longer than flagellum, with double row of plumose setae. Flagellum with six articles; last article with 4 terminal simple setae.

Labrum (Fig. 1F). Rounded, with apex provided with hairs.

Mandibles. Right mandible (Fig. 1G) with incisor process having 6 denticles. Left 
mandible (Fig. 1H) with incisor process having 9 or 10 denticles; lacinia mobilis with 8 denticles. Both mandibles with spine row of 5 serrate spines. Mandibular palp uniarticulate with row of long plumose setae and terminating in a spine; terminal spine about 2 times longer than wide. Molar processes as illustrated (Figs. 1G, I).

Labium (Fig. 1J). Outer and distal margin spinulate. Palp with long hairs on margins and spinulate on outer margin. Quadrangular and ending in a long, acuminate inner tip.

Maxillule (Fig. 1K). Inner endite bearing 4 terminally setulate setae. Outer endite with 11 distal spines, 2 subterminal setae and long hairs on outer face.

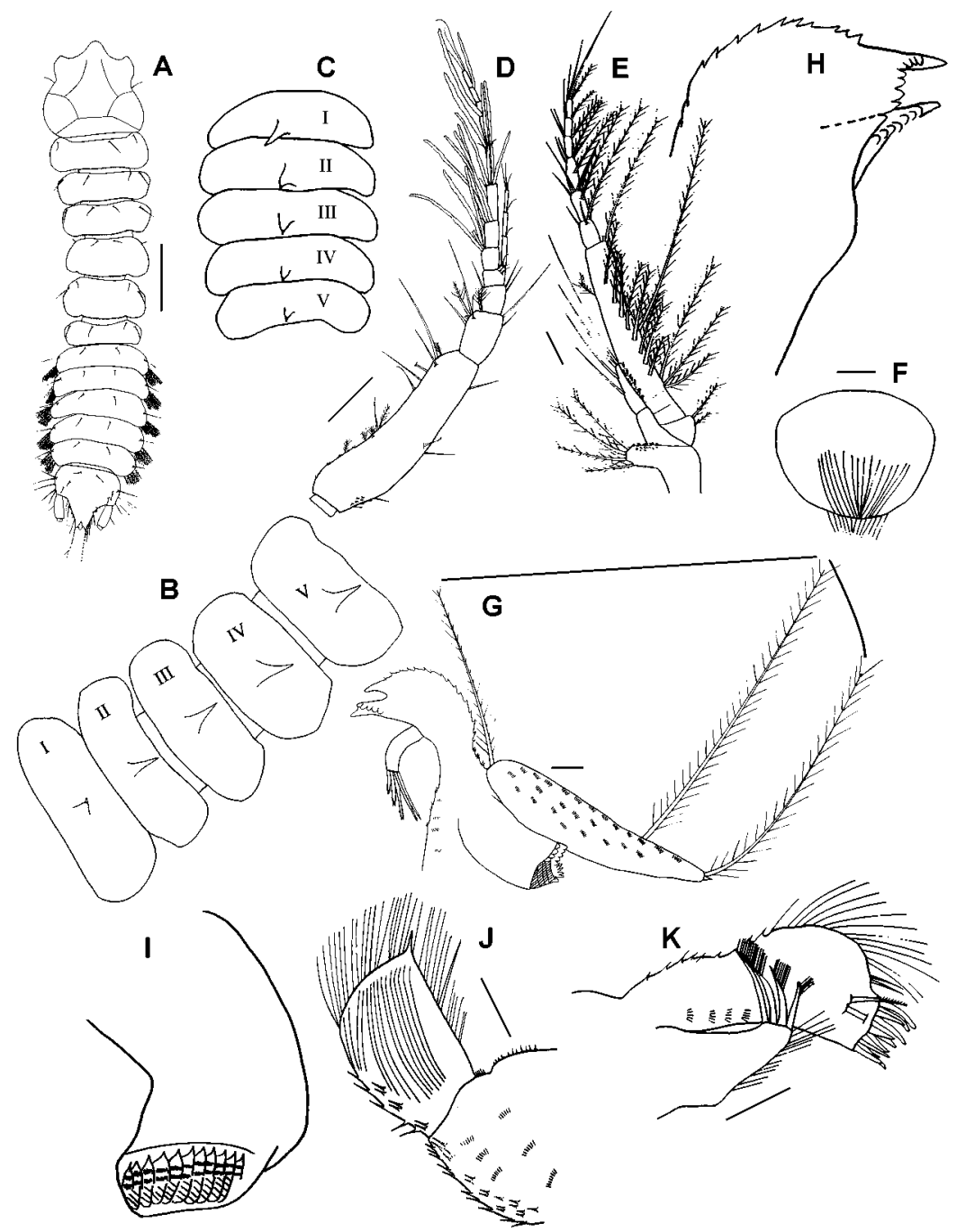

FIGURE 1. Transkalliapseudes spinulata, male holotype. A, dorsal view of body; B, ventral view of pereon, showing hyposphaenia; $\mathrm{C}$, ventral view of pleon, showing hyposphaenia; $\mathrm{D}$, antennule; $\mathrm{E}$, antenna; F, labrum; G, right mandible; $\mathrm{H}$, incisor process and lacinia mobilis of left mandible; I, molar process of left mandible; J, labium; $\mathrm{K}$, maxillule. Scale bars: $\mathrm{A}=0.5 \mathrm{~mm}$; $\mathrm{D}=0.2 \mathrm{~mm}$; $\mathrm{E}=$ $0.1 \mathrm{~mm} ; \mathrm{F}, \mathrm{G}, \mathrm{J}, \mathrm{K}=0.05 \mathrm{~mm}$. 


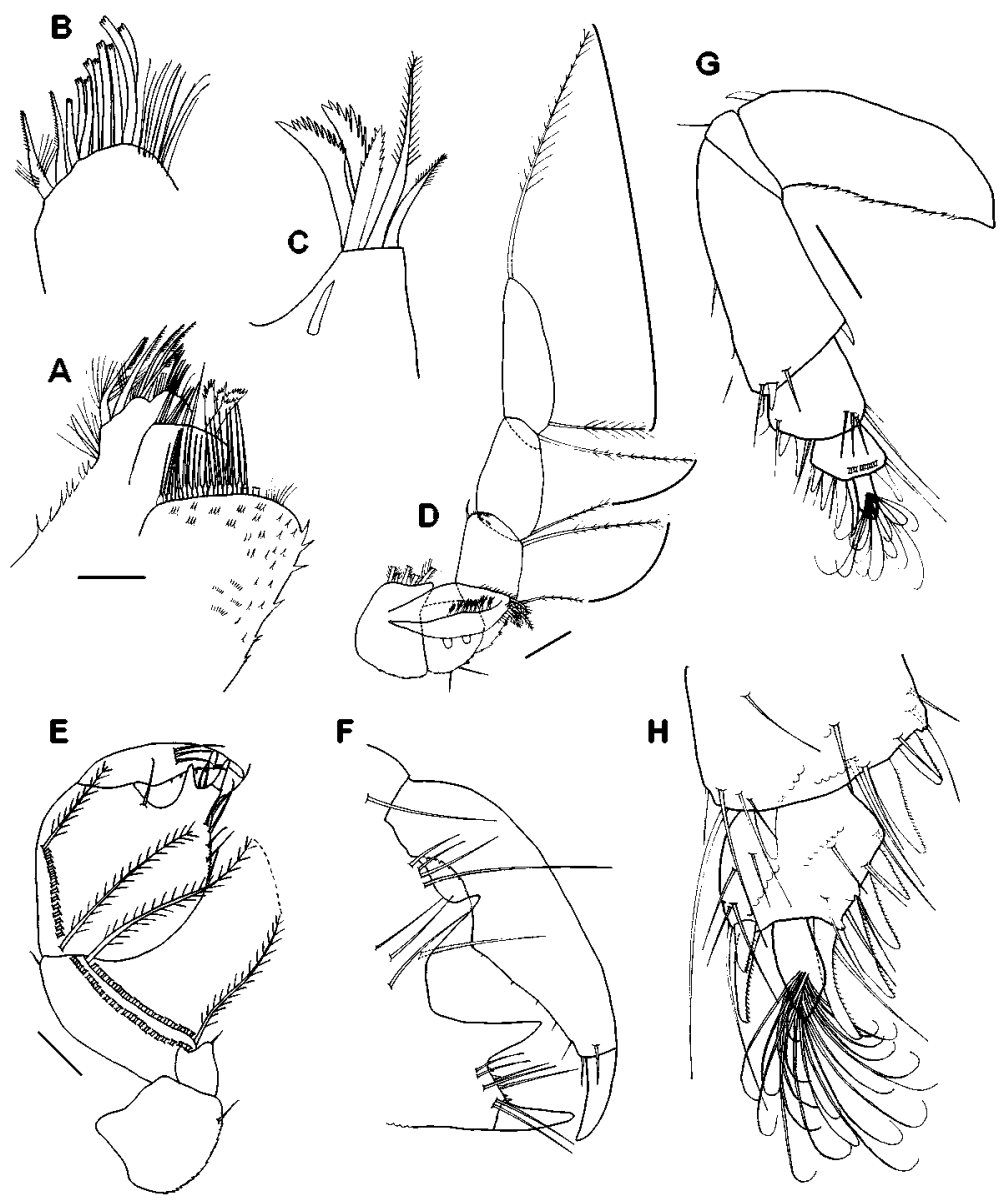

FIGURE 2. Transkalliapseudes spinulata, male holotype. A, maxilla; B, inner lobe of moveable endite; C, outer lobe of fixed endite; D, maxilliped; E, cheliped (inner surface); F, chela (outer surface); G, pereopod I (inner surface); H, distal portion of pereopod I (outer surface). Scale bars: A $=0.05 \mathrm{~mm} ; \mathrm{D}=0.1 \mathrm{~mm} ; \mathrm{E}, \mathrm{G}=0.2 \mathrm{~mm}$.

Maxilla (Fig. 2A). Inner lobe of fixed endite with posterior row of 2 serrate setae and with long row of plumose setae. Outer lobe of fixed endite (Fig. 2C) with multi-toothed spiniform setae on inner half and several serrate setae on outer half. Inner lobe of moveable endite (Fig. 2B) with about 9 spiniform setae terminating in 3 cusps and with 1 plumodenticulate and 1 serrate seta. Outer lobe of moveable endite with 3 serrate and 2 plumodenticulate setae. Outer margin spinulate.

Maxilliped (Fig. 2D). Basal article fringed with plumose setae along outer margin. Palp with double row of long plumose setae on inner margin. Endite with numerous long hairs on lateral margins and with plumose setae on distal margin, and with 2 coupling hooks.

Epignath. Not recovered. 


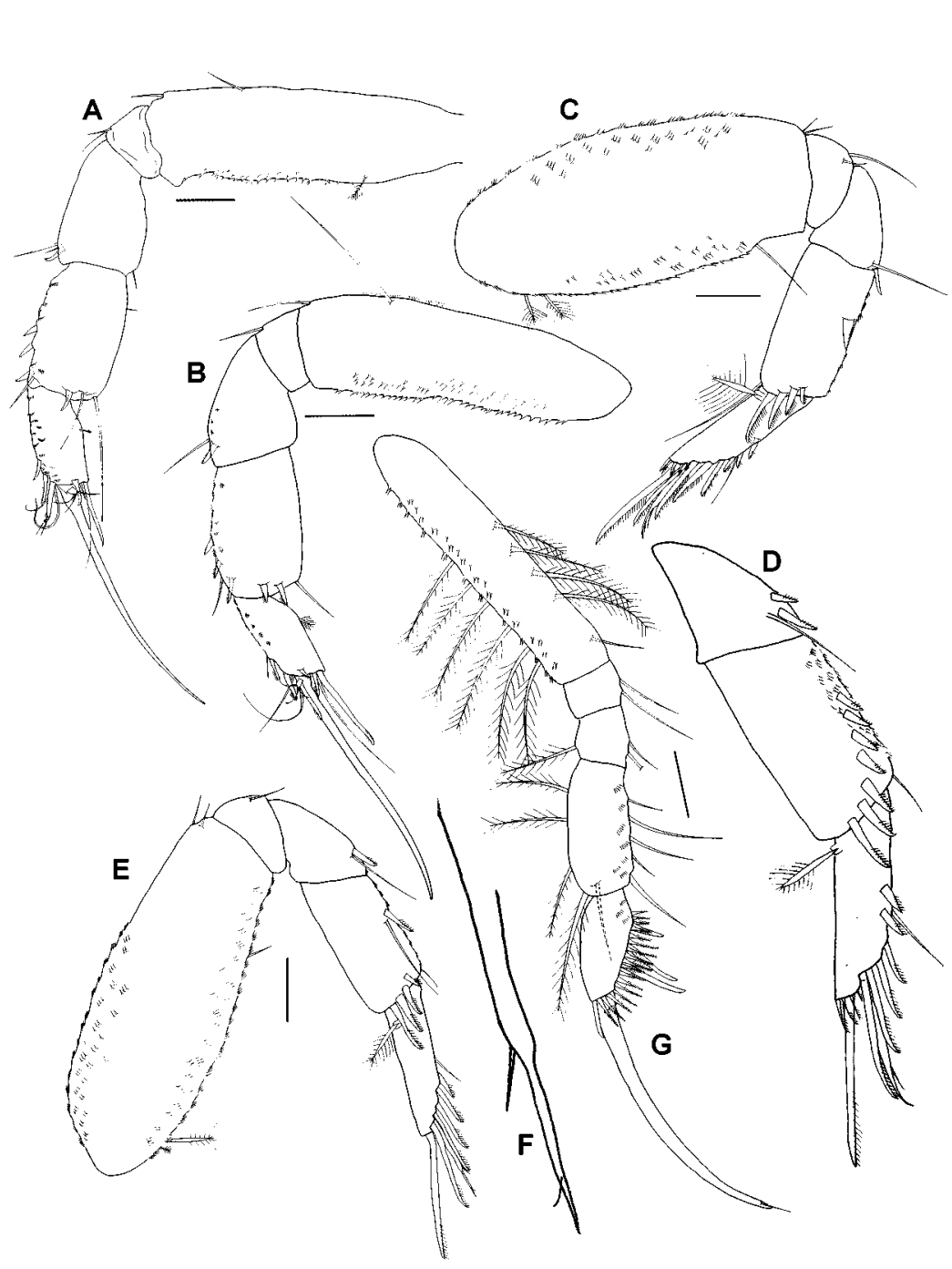

FIGURE 3. Transkalliapseudes spinulata, male holotype. A, pereopod II; B, pereopod III; C, pereopod IV; D, distal portion of pereopod IV (outer surface); E, pereopod V; F, pereopod V dactylus; G, pereopod VI. Scale bars: $0.1 \mathrm{~mm}$.

Cheliped (Figs. 2E, F). Basis with 1 simple ventrodistal seta and ventral margin spinulate. Merus longer than broad, with 1 simple ventrodistal seta. Carpus about 2.5 times longer than broad, with double row of long, plumose setae and 1 short simple seta on dorsodistal corner. Propodus robust and ventral margin greatly rounded proximally, with diagonal row of long, plumose setae and with small, rounded tubercles at mid-region; fixed finger two-thirds or more length of dactylus, with several simple setae on outer surface, with distal spine; cutting edge with 1 large tooth and with 5 spinules and 2 simple setae between tooth and distal spine; palm with 1 simple seta on inner surface and several simple setae on outer surface and with 1 large tooth. Dactylus outer surface with 3 setae proximal to claw and with 1 simple seta adjacent to claw; cutting edge with triangular 
protuberance about midway and with about 11 spinules increasing in length distal to triangular projection; claw present. Exopodite absent.

Pereopod I (Figs. 2G, H). Basis almost 3 times longer than wide, with 1 ventrodistal spine and with spinules on dorsal margin. Ischium with 1 simple seta on ventral margin. Merus longer than wide, wider and shorter than basis, with 1 dorsal and 1 ventral spine. Carpus about one-third length of merus, with 2 ventrodistal and 1 dorsodistal spine and with round tubercles on outer surface. Propodus shorter than carpus, with 3 ventral, 1 ventrodistal, and 2 dorsodistal serrate spines and with round tubercles on outer surface. Dactylus represented by a sensory organ. Exopodite absent.

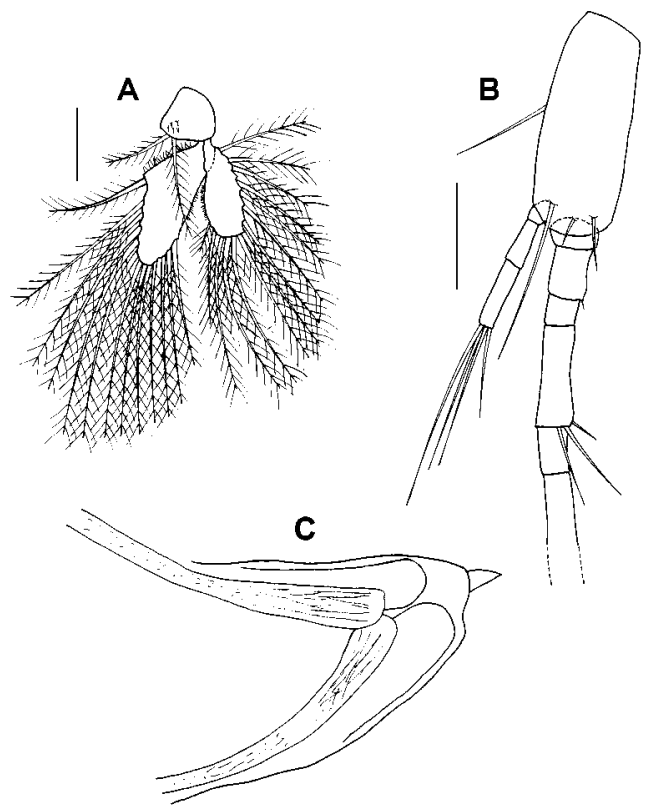

FIGURE 4. Transkalliapseudes spinulata, male holotype. A, pleopod; B, uropod; C, genital cone. Scale bars: $\mathrm{A}=0.2 \mathrm{~mm} ; \mathrm{B}=0.1 \mathrm{~mm}$.

Pereopod II (Fig. 3A). Basis about 3 times longer than wide, with spinules on dorsal margin and 2 short, simple setae on ventral margin. Ischium with 2 short, simple setae on ventral margin. Merus about same length as carpus, with one spine on distal inner surface. Carpus about 1.5 times longer than wide, with 2 spines on ventral margin, 1 distal spine on inner surface and 1 distal spine on outer surface. Propodus about one-third length of basis, ventral and dorsodistal margins with 2 serrate spines, ventrodistal spine with 2 terminal setae, and ventral margin and outer surface with spinules. Dactylus shorter than basis; sensory organ present near base, with 3 aesthetascs.

Pereopod III (Fig. 3B). Similar to pereopod II. Basis with 1 short and 1 long, simple seta on ventral margin. Ischium with 1 short, simple seta on ventral margin. Carpus with 2 distal spines on outer surface.

Pereopod IV (Figs. 3C, D). Basis about 2.3 times longer than wide, with spinules on 
dorsal and ventral margins, 2 short simple setae on ventrodistal corner and 1 simple seta on dorsal margin. Ischium with 1 long simple seta on ventral margin and 1 short simple seta on outer surface. Merus shorter than carpus, with 1 ventrodistal spine and 2 spines on outer surface. Carpus with 4 spines on inner surface, 7 spines on outer surface and 1 distal spine. Propodus terminating in spines increasing in length distally and terminally with 5 short, comb-like spines. Dactylus shorter than propodus, with 2 distal sensory setae.

TABLE 1. Generic characters of the subfamily Kalliapseudinae

\begin{tabular}{|c|c|c|c|}
\hline Characters & Alokalliapseudes & Cristapseudes & Kalliapseudes \\
\hline Antenna peduncle: setal type of last article & simple & plumose & plumose \\
\hline Exopodite on cheliped & absent & absent & present \\
\hline $\begin{array}{l}\text { Propodus of female cheliped slender (longer than } \\
\text { carpus) }\end{array}$ & yes & no & no \\
\hline Sexually dimorphic chelipeds & present & present & present \\
\hline Exopodite on pereopod I & absent & absent & present \\
\hline Digitiform lobe on dactylus of pereopods II and III & present & absent & present \\
\hline $\begin{array}{l}\text { Tuft of sensory setae on dactylus of pereopods IV } \\
\text { and V }\end{array}$ & present & present & $\begin{array}{l}\text { Present or } \\
\text { absent }\end{array}$ \\
\hline Tuft of sensory setae on dactylus of pereopod VI & absent & absent & absent \\
\hline
\end{tabular}

continued.

\begin{tabular}{|c|c|c|c|}
\hline Characters & Mesokalliapseudes & Monokalliapseudes & Transkalliapseudes \\
\hline Antenna peduncle: setal type of last article & simple & plumose & plumose \\
\hline Exopodite on cheliped & absent & absent & absent \\
\hline $\begin{array}{l}\text { Propodus of female cheliped slender } \\
\text { (longer than carpus) }\end{array}$ & yes & no & unknown \\
\hline Sexually dimorphic chelipeds & absent & present & unknown \\
\hline Exopodite on pereopod I & absent & present & absent \\
\hline $\begin{array}{l}\text { Digitiform lobe on dactylus of pereopods II } \\
\text { and III }\end{array}$ & present & present & present \\
\hline $\begin{array}{l}\text { Tuft of sensory setae on dactylus of } \\
\text { pereopods IV and V }\end{array}$ & present & present & absent \\
\hline $\begin{array}{l}\text { Tuft of sensory setae on dactylus of } \\
\text { pereopod VI }\end{array}$ & absent & present & absent \\
\hline
\end{tabular}

Pereopod V (Figs. 3E, F). Basis narrower than pereopod IV, about 2.6 times longer than wide and with spinules on dorsal and ventral margins. Ischium with 1 simple seta on inner surface near ventral margin. Merus with 1 spine on inner surface. Carpus with 1 proximal and 4 distal serrate spines and with spinules on ventral margin. Propodus with 6 
serrate spines increasing in length distally. Dactylus shorter than propodus, with 2 distal sensory setae.

Pereopod VI (Fig. 3G). Basis with 6 long, plumose setae and spinules on dorsal margin and with 4 plumose and 1 simple setae on outer surface. Merus with 1 plumose seta on dorsal margin and 2 simple setae on ventral margin. Carpus with 4 plumose setae on dorsal margin and 5 simple setae on ventral margin. Propodus with 4 long spines and 17 short comb-like spines. Dactylus shorter than basis, with 1 distal seta.

Pleopods (Fig. 4A). Basal article with 2 plumose setae. Exopodite with 14 plumose setae. Endopodite with 13 plumose setae.

Uropods (Fig. 4B). Exopodite with 3 articles, last article with 4 simple setae. Endopodite multiarticulated (exact number difficult to determine due to incomplete fusion in some of the articles).

Etymology. Named in reference to the numerous spinules on the appendages.

Remarks. Transkalliapseudes spinulata superficially resembles Kalliapseudes struthi Bamber, 2005, which is known from Esperance Bay, Southwest Australia, by the similar shape and setation of the pereopods IV and V dactylus. It can be distinguished from $K$. struthi by the following characters: 1) the armature of the male cheliped, 2) lack of exopodites on cheliped and pereopod I, 3) 1 distal seta on pereopod VI dactylus (tip of dactylus bifurcate in K. struthi) and 4) uropodal exopodite with 3 articles (only 2 articles in K. struthi). As mentioned above, T. spinulata differs from all other known kalliapseudids by having numerous granular-like spinules covering the appendages. This is the first kalliapseudid reported from the Northwest Australian Shelf.

\section{Acknowledgements}

We wish to thank Roger Springthorpe, Australian Museum (Natural History), for the loan of material and Dr. Modest Guțu for much needed advice and sharing his knowledge of this group of tanaidaceans. We also thank Jürgen Guerrero Kommritz, Kim Larsen and the two anonymous reviewers, who provided insightful comments on the manuscript. This research was supported by a grant from the National Science Foundation (DEB-0529749).

\section{Literature cited}

Băcescu, M. (1978) Contribution to the knowledge of Monokonophora (Crustacea: Tanaidacea) from the NW of the Indian Ocean. Memoriile Secţiei Ştiinţifice, Seria IV, Editura Academiei Republicii Socialiste România, 1, 197-220.

Băcescu, M. (1980) Contributions to the knowledge of some Kalliapseudidae (Crustacea, Tanaidacea) from the NW of the Indian Ocean. Travaux du Muséum National d'Histoire naturelle "Grigore Antipa" , 22, 359-379.

Bamber, R.N. (2000) Additions to the apseudomorph tanaidaceans (Crustacea: Peracarida) of Hong 
Kong. In: Morton, B. (Ed.), The Marine Flora and Fauna of Hong Kong and Southern China Sea. Proceedings of the Tenth International Marine Biological Workshop: The Marine Flora and Fauna of Hong Kong and Southern China, Hong Kong. 6-26 April 1998, Hong Kong University Press, pp. 37-52.

Bamber, R.N. (2005) The tanaidaceans (Arthropoda: Crustacea: Peracarida: Tanaidacea) of Esperance, Western Australia, Australia. In: Wells, F.E., Walker, D.I., \& Kendrick, G.A., (Eds.), The marine flora and fauna of Esperance, Western Australia. Western Australian Museum, Perth, pp. 613-727.

Bamber, R.N., Bird, G.J., \& Angsupanich, S. (2003) Tanaidaceans (Crustacea: Peracarida) from Thailand: new records and new species. Asian Marine Biology, 18: 35-69.

Dallwitz, M.J., Paine, T.A., \& Zurcher, E.J. (1993) User's guide to the DELTA System: a general system for processing taxonomic descriptions, $4^{\text {th }}$ edition. http://biodiversity.uno.edu/delta/.

Guțu, M. (1972) Phylogenetic and systematic considerations upon the Monokonophora (Crustacea, Tanaidacea) with the suggestion of a new family and several subfamilies. Revue Roumaine de Biologie, Série Zoologie, 17(5), 297-305.

Guț, M. (1996) The synoptic table and key to superspecific taxa of recent Apseudomorpha (Crustacea, Tanaidacea). Travaux du Muséum National d'Histoire naturelle “Grigore Antipa”, 35, 135-146.

Guțu, M. (2001) New changes in the systematics of the suborder Apseudomorpha (Crustacea: Tanaidacea). Travaux du Muséum National d'Histoire naturelle “Grigore Antipa”, 43:65-71.

Guțu, M. (2006) New Apseudomorph taxa (Crustacea, Tanaidacea) of the world ocean, Bucuresti: Curtea Veche, 318 pp.

Hansknecht, T., Heard, R.W., and Bamber, R. (2002) Tanapseudes gutui, a new species of apseudomorphan tanaidacea (Crustacea: Peracarida) from the Caribbean Sea and the taxonomic status of the family Tanapseudidae Băcescu, 1978. Gulf and Caribbean Research, 14, 67-74.

Lang, K. (1956) Kalliapseudidae, a new family of Tanaidacea. In: Wingstrand K.G. (Ed.), Bertil Hanstroem. Zoological papers in honorus in his $65^{\text {th }}$ birthday, Nov. $20^{\text {th }}$, 1956. Zoological Institute, Lund, pp. 205-225.

Larsen, K. (2003) Proposed new standardized anatomical terminology for the Tanaidacea (Peracarida). Journal of Crustacean Biology, 23(3), 644-661.

Sieg, J. (1986) Crustacea Tanaidacea of the Antarctic and Subantarctic. 1. On material collected at Tierra del Fueggo, Isla de los Estados, and the West Coast of the Antarctic Peninsula. In: Kornicker, L.S., (Ed.), Biology of the Antarctic Seas XVIII. Washington, 45, pp. 1-180.

Stebbing, T.R.R. (1910) No. VI. Isopoda from the Indian Ocean and British East Africa. The Percy Sladen Trust Expedition to the Indian Ocean in 1905. The Transactions of the Linnean Society of London, Series 2, Zoology, 14, 83-122 (plates V-XIV). 